\title{
The Yuge Effect of Racist Resentment on Support for Donald Trump and... Attitudes about Automobile Fuel Efficiency Requirements?
}

\author{
L.J Zigerell \\ Associate Professor of Politics and Government \\ Illinois State University \\ 404 Schroeder Hall \\ Normal, IL 61790 \\ ljzigerell@ilstu.edu \\ @LJZigerell
}

Abstract. Recent political science research has used a relatively new measure of racist attitudes - referred to as racist resentment, among other labels-to support inferences about racist attitudes and vote choice in the 2016 U.S. presidential election. Analysis of data from the 2016 Cooperative Congressional Election Study indicated that this racist resentment measure predicted vote choice for Donald Trump but also nontrivially predicted phenomena that theoretically have little-to-no racial content such as attitudes about environmental policies. These results suggest that the racist resentment measure captures too much nonracial content to be useful for estimating the association of racism with outcome variables.

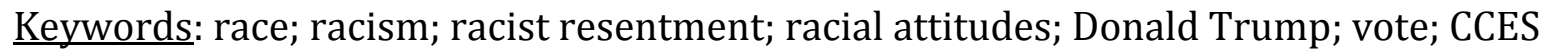

Acknowledgements. Thanks to Brian Schaffner, Marc Hooghe, and Ruth Dassonneville for comments and suggestions.

Note: The author's Institutional Review Board does not require review and approval for analysis of de-identified datasets such as the CCES or the ANES 2016 Time Series Study. 
Did racism influence vote choice in the 2016 U.S. presidential election? Two recent political science studies had titles that made such causal claims: "Understanding White Polarization in the 2016 Vote for President: The Sobering Role of Racism and Sexism" (Schaffner et al. 2018) and "Explaining the Trump Vote: The Effect of Racist Resentment and AntiImmigrant Sentiments" (Hooghe and Dassonneville 2018). These analyses reported on associations of an intended or reported vote for Donald Trump in the 2016 U.S. presidential election with a relatively new measure of racist attitudes. Items from this new measure appeared on the widely-used publicly-available Common Content portion of the 2016 Cooperative Congressional Election Study (CCES, Ansolabehere and Schaffner 2017), so it is important for political science researchers and readers to be informed of the quality of the inferences produced by this measure. The analyses reported below suggest that researchers and readers should be skeptical of estimates from analyses that use this measure to estimate the causal effect of racist attitudes.

\section{"Denial of Racism"}

The racial attitudes measure in the aforementioned studies was constructed from items in which participants were invited to respond on a five-point agree/disagree scale to statements of: "I am angry that racism exists", "White people in the U.S. have certain advantages because of the color of their skin", and "Racial problems in the U.S. are rare, isolated situations". ${ }^{1}$ Schaffner et al. (2018) described the items as "three items that capture the extent to which an individual acknowledges and empathizes with racism" (p. 17) and described a combined measure of these three items as a "denial of racism scale" (p. 28). However, this measure might not be a good measure for assessing the extent to which a participant is "more acknowledging of racism" or "more denying of the existence of racism" (Schaffner et al. 2018, p. 18), given that the "Racial problems in the U.S. are rare, isolated situations" item measures perceptions about "racial problems" and not about "racism" per se, and given that no responses to the "I am angry that racism exists" item can be properly interpreted as a denial of racism.

A more face valid method for assessing acknowledgement of racism is permitted by the American National Election Studies 2016 Time Series Study (American National Election Studies et al. 2017). Participants were asked to indicate on a five-point scale their responses for various target groups to the item: "How much discrimination is there in the United States today against each of the following groups?". The ANES 2016 Time Series Study dataset had 1,098 non-Hispanic White participants who reported voting for Donald Trump in the 2016 U.S. presidential election and received the discrimination items for targets of Blacks and Whites. Eighteen of these 1,098 participants (1.6\%) rated discrimination against Blacks in the United States as "None at all" and rated discrimination against Whites in the United States as more than "None at all", but 131 of these 1,098 participants (11.9\%) rated discrimination against Whites in the United States as "None at

\footnotetext{
1 The first item was drawn from Spanierman and Heppner (2004), and the second and third items were drawn from Neville et al. (2000). The CCES had a fourth, related item: "I often find myself fearful of people of other races"; this item is not included in the main analyses, but information on results including this fourth item are available in the supplemental material.
} 
all" and rated discrimination against Blacks in the United States as more than "None at all".2 Thus, by this measure, there does not appear to be widespread denial among non-Hispanic White Donald Trump voters of anti-Black racism in the United States; furthermore, more non-Hispanic White Trump voters denied discrimination against Whites than denied discrimination against Blacks. ${ }^{3}$ This nuance is unable to be captured in a CCES racist resentment item that asks about white privilege but asks about neither white disadvantage nor nonwhite privilege.

\section{"Racist Resentment"}

The three-item 2016 CCES racial attitudes measure has been labeled "racist resentment" and has been referred to as a type of scale that "tend[s] to assess to what extent respondents minimize the occurrence of racist prejudice" (Hooghe and Dassonneville 2018: 3). To assess the extent to which this "racist resentment" measure can be used to make inferences about the influence of racist attitudes, I followed the logic of prior research (e.g., Kinder and Sanders 1996, Rabinowitz et al. 2009, and Zigerell 2015) and used this racist resentment measure to predict phenomena that have little-to-no theoretical association with racism. Data were drawn from participants who were included in both the pre- and post-election Common Content portion of the 2016 Cooperative Congressional Election Study, with a racist resentment measure that summed the three aforementioned items. ${ }^{4}$ Reported analyses were restricted to non-Hispanic Whites, and models controlled for participant sex, age, education, family income, partisanship, and ideology. ${ }^{5}$ For the main analyses, logistic regressions were used to predict values of dichotomous outcome variables, and linear regressions were used to predict values of nondichotomous outcome variables. Statistical analyses were conducted in Stata (StataCorp 2017), with predicted values estimated with Stata's margins command and with Clarify (King et al. 2000, Tomz et al. 2001). Non-dichotomous variables were placed on a 0-to-1 scale. Reported results are unweighted, with information on weighted results and other alternate specifications available in the supplemental material.

\footnotetext{
${ }^{2}$ Thirty-four of these 1,098 participants (3.1\%) rated both the discrimination against Blacks and the discrimination against Whites at "None at all".

${ }^{3}$ Expanding the denial of racism measure to include non-Hispanic White Donald Trump voters who rated the discrimination against Blacks lesser than the discrimination against Whites captured 132 total participants (12.0\%).

${ }^{4}$ Summing the items follows the method in Hooghe and Dassonneville (2018). More complex methods used to combine the racist resentment items produced correlations above 0.90 between these racist resentment measures.

${ }^{5}$ Note that the model specification and variable coding in the present study differ from the model specifications and variable codings in Schaffner et al. (2018) and Hooghe and Dassonneville (2018), which differ from each other in model specification and variable coding. Please also note that, in addition to predicting variables regarding 2016 U.S. presidential election vote choice, Schaffner et al. (2018) predicted reported presidential vote changes between 2012 and 2016, such as a switch from voting for Barack Obama in 2012 to voting for Donald Trump in 2016. And please note that Hooghe and Dassonneville (2018) also found that anti-immigrant sentiments predicted a vote for Trump relative to other candidates, and that, as indicated on the second page of their article, "anti-immigrant sentiments are highly effective in explaining an extreme-right vote" and are "a stable and cross-culturally equivalent measurement scale" (citations omitted).
} 
The top panel of Figure 1 reports results from logistic regressions that used the racist resentment measure and controls to predict the dichotomous outcome variables of: [1] a vote for Donald Trump in the 2016 U.S. presidential election (coded 0 for a vote for Hillary Clinton), [2] opposition to allowing gays and lesbians to marry legally, [3] opposition to the Highway and Transportation Funding Act, [4] opposition to a woman always being allowed to obtain an abortion as a matter of choice, and [5] a vote for Hillary Clinton in the 2016 Democratic Party primary election (coded 0 for a vote for Bernie Sanders). The bottom panel of Figure 1 reports results from linear regressions that used the racist resentment measure and controls to predict the non-dichotomous variables of: [6] a summed scale of attitudes about environmental policy proposals, [7] support for decreased state spending on transportation and infrastructure, [8] support for decreased state spending on education, [9] job approval for black Republican South Carolina senator Tim Scott among those who provided a substantive response, and [10] job approval for white Republican South Carolina senator Lindsey Graham among those who provided a substantive response. For the top panel, values are predicted probabilities when the racist resentment measure is at its lowest value and at its highest value, with all other model variables at their means; for the bottom panel, values are predicted responses on a 0 -to- 1 scale when the racist resentment measure is at its lowest value and at its highest value, with all other model variables at their means. Reported p-values are for the racist resentment measure. Responses for outcome variables involving Tim Scott and Lindsey Graham were limited to South Carolina participants. 

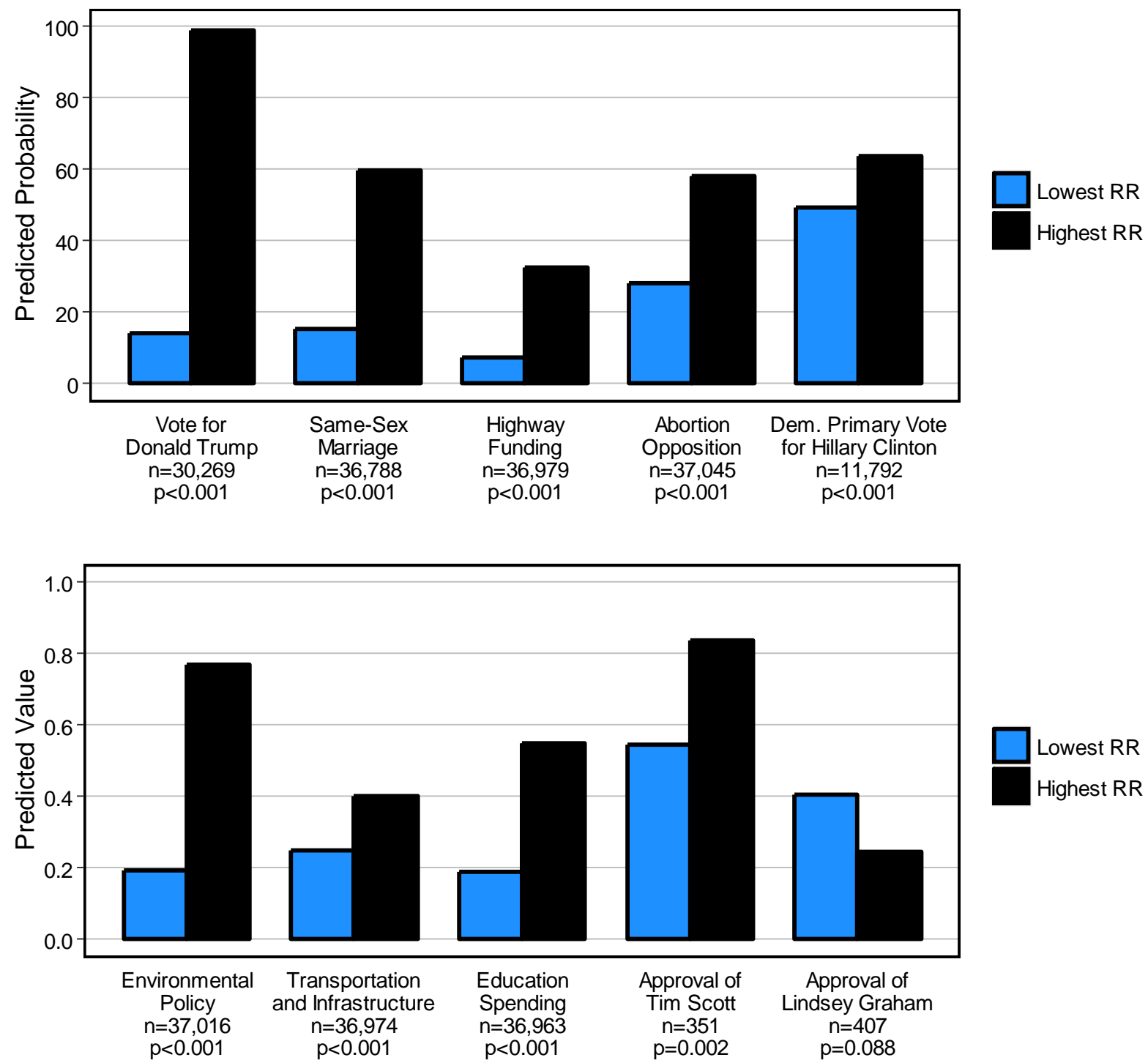

Figure 1. Association of Racist Resentment with Selected Outcome Variables

Note: The figure reports predicted probabilities from logistic regressions (top panel) and predicted values from linear regressions (bottom panel) for non-Hispanic White participants to the indicated outcome variables, in unweighted analyses that controlled for participant sex, age, education, family income, partisanship, and ideology. Blue/gray bars indicate predicted values when racist resentment is at its lowest value, and black bars indicate predicted values when racist resentment is at its highest value, with all other model variables at their means. Data source: CCES 2016. The figure was produced in R (R Core Team 2018) using ggplot2 (Wickham 2016). 
For most or all models in Figure 1, the association between racist resentment and the outcome variable was of nontrivial size, such as the predicted probability of opposition to same-sex marriage being legal rising from 15 percent at the lowest level of racist resentment to 59 percent at the highest level of racist resentment with all other model variables at their means, and the predicted response on the 0 -to-1 environmental policy measure correspondingly rising from 0.15 to 0.80 .6 Moreover, prior research (Meyer and Woodard 2017, see also White and Oldendick 2016) indicated that racial resentment associated at similar levels with support for Tim Scott and Lindsay Graham, even though these two senators were both South Carolina Republicans and thus it might be expected that a measure of racist attitudes would associate differently with these two similar senators, one of whom was White and one of whom was Black; however, in the 2016 CCES, racist resentment had a stronger positive association with job approval for the black Republican South Carolina senator than for the white Republican South Carolina senator. ${ }^{7}$

Figure 1 indicates that the racist resentment measure predicted a reported vote for Donald Trump in the 2016 U.S. presidential election, even controlling for partisanship and ideology. Many political science researchers and readers might interpret this predictive power as evidence that racism had a causal relationship with the decision to vote for Donald Trump. However, the same inference threshold would produce the inference that racism had a powerful causal relationship with attitudes about environmental policy.

One interpretation of the Figure 1 results is that the estimated association between racist resentment and the outcome variables completely reflects the direct influence of racism and the causal effect of racial spillover (see Tesler 2012) in which considerations of race inform attitudes that are not theoretically related to race, such as, in this analysis, attitudes about environmental policy. This is possible and would be an interesting finding, but assessing whether such spillover can account for the associations appears to require a more sophisticated research design than permitted by the data available in the 2016 CCES.

Another interpretation of the Figure 1 results is that the association of the racist resentment measure with presumably nonracial outcome variables reflects non-causal associations but that associations for racial or plausibly racialized outcome variables that are larger than these non-causal associations can be interpreted as causal: for example, the association of the racist resentment measure with vote choice for Donald Trump was larger than the association of the racist resentment measure with the other Figure 1 outcome variables, so that it can be inferred that the excess association for the Trump vote outcome variable reflects the influence of racism. However, given the large association of the racist

\footnotetext{
${ }^{6}$ See the supplemental material for more detailed regression output for the Figure 1 models and for information on robustness checks. The $\mathrm{p}$-value for the racist resentment measure fell above $\mathrm{p}=0.05$ for alternate model specifications reported in the supplemental file for South-Carolina-only outcome variables 9 and 10, respectively job approval for Tim Scott and job approval for Lindsey Graham.

${ }^{7}$ Note that the sample of South Carolina participants for outcome variables 9 and 10 differs from the national sample for the other outcome variables and that some outcome variables-especially the scale of environmental policy attitudes - might be measured better than other outcome variables. The main purpose of Figure 1 is not to compare association sizes across models but rather to illustrate that the analysis could be used to support the inference that racism has a causal effect on these outcome variables.
} 
resentment measure with presumably nonracial outcome variables, this inferential method would effectively eliminate the ability of the racist resentment measure to detect the influence of racism for analyses in which the ability to detect the influence of racism is most useful, namely, for those outcome variables in which the influence of racism is small-tomoderate but meaningful. For example, see Figure 2, which reports association sizes for the four 2016 CCES items measuring attitudes about policing policies (top panel) and for the four CCES items measuring attitudes about environmental policies (bottom panel). ${ }^{8}$ Racist resentment association sizes are meaningfully large for the policing policy outcome variables, with racism at least doubling the point estimates for opposition; however, the larger racist resentment associations for the environmental policy outcome variables undercuts a naïve interpretation of the policing policy results as causal, such that racist resentment provides little-to-no evidence that racism influences policing policy preferences, even though policing policy is a plausible domain in which racism might influence policy preferences.

${ }^{8}$ See the supplemental material for item text for these items. 

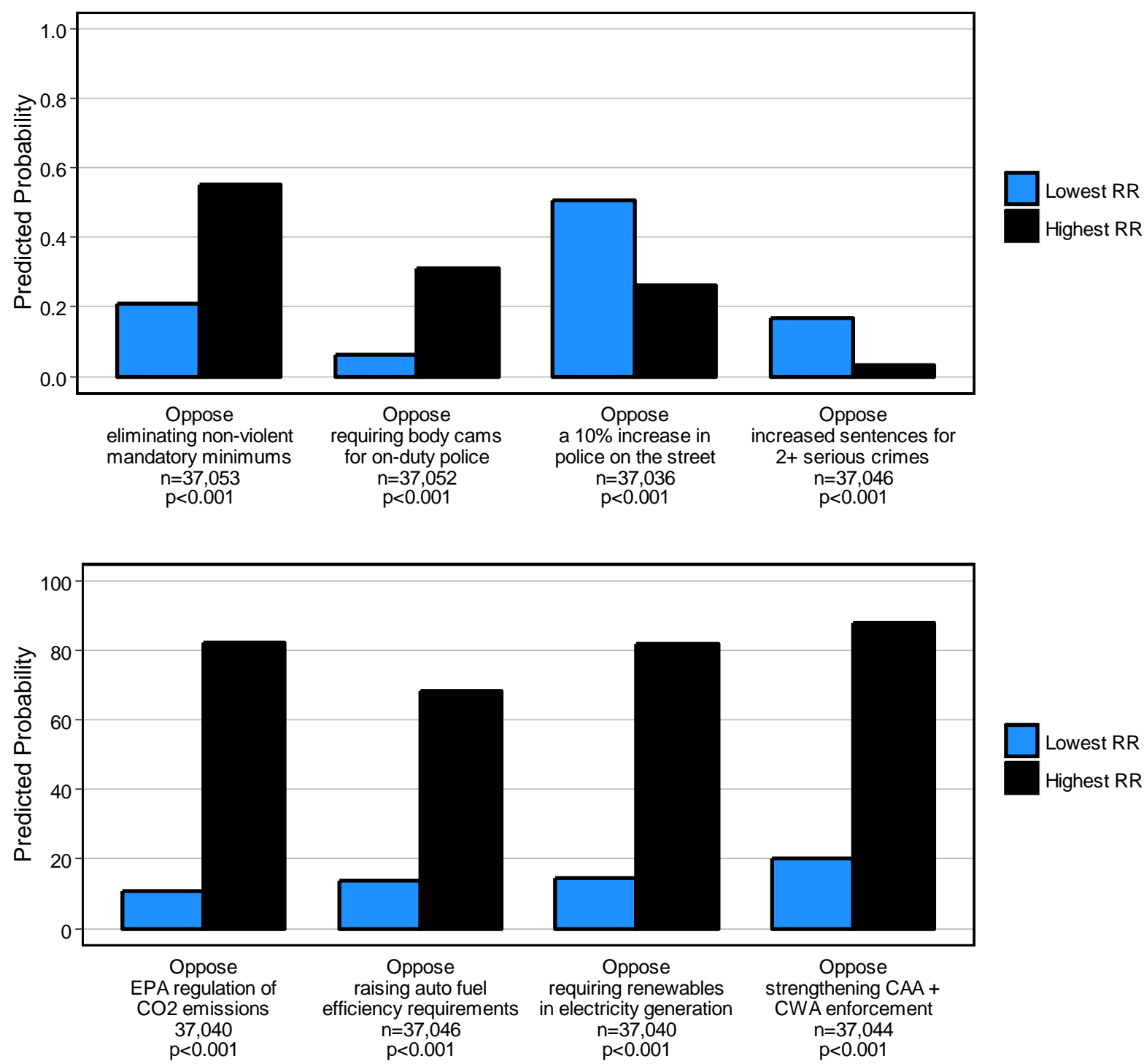

Figure 2. Association of Racist Resentment with Policy Preferences about Policing and the Environment

Note: The figure reports predicted probabilities from logistic regressions of reported opposition to the selected policy proposals from non-Hispanic White participants, in unweighted analyses that controlled for participant sex, age, education, family income, partisanship, and ideology. Blue/gray bars indicate predicted values when racist resentment is at its lowest value, and black bars indicate predicted values when racist resentment is at its highest value, with all other model variables at their means. Data source: CCES 2016. The figure was produced in R (R Core Team 2018) using ggplot2 (Wickham 2016). 
Moreover, this inferential method would presumably require estimated effect sizes of racism to be discounted by the size of the associations for the presumably nonracial outcome variables and would require a statistical test of whether the association of the racist resentment measure with a presumably nonracial outcome variable differs from the association of the racist resentment measure with the item of interest. It is more straightforward for researchers to use a measure of racism that has more face validity than a measure that imputes racism based in part on how angry the participant reports being about the existence of racism.

\section{Conclusion}

Estimating the effect of racist attitudes is an important task, and the real-world importance of this task and its potential influence on policy and the political debate is a compelling reason for researchers and readers to be careful inferring causal relationships from correlational data. The above analyses do not indicate that racism had no influence on vote choice in the 2016 U.S. presidential election, but the analyses do suggest that, even with statistical control for self-reported partisanship and ideology, racist resentment does not permit a pure measure of racist attitudes that can be naively interpreted for making causal claims based on associations of the measure with outcome variables.

The racist resentment measure is useful for sorting Donald Trump voters and Hillary Clinton voters on perceptions of the extent which racial problems are rare and isolated, willingness to signal anger about racism, and perceptions of whether White people in the United States have advantages because of their skin color. But the racist resentment measure is also useful for sorting persons by their attitudes about environmental policy, and the fact that a variable can sort cases in a way that associates with another variable in the presence of imperfect statistical control is not sufficient to establish a causal connection between the variables.

If cross-sectional research using racist resentment or similar measures can establish only an association with an outcome variable, political science researchers and readers might be better served with an analysis that in addition or instead exploits the strong causal inference of an experiment to assess the association between an outcome variable and participant racial discrimination. Informing readers about whether Donald Trump voters report a different average level of agreement that they are angry that racism exists than Hillary Clinton voters report does not appear to be as valuable as informing readers whether Donald Trump voters treat non-White experimental targets differently than they treat White experimental targets and whether any difference in treatment differs from the difference in treatment among Hillary Clinton voters. 


\section{References}

American National Election Studies, University of Michigan, and Stanford University. 2017. ANES 2016 Time Series Study. Ann Arbor, MI: Inter-university Consortium for Political and Social Research [distributor], 2017-09-19. https://doi.org/10.3886/ICPSR36824.v2.

Ansolabehere, Stephen, and Brian F. Schaffner. 2017. Cooperative Congressional Election Study, 2016: Common Content. [Computer File] Release 2: August 4, 2017. Cambridge, MA: Harvard University [producer]. http://cces.gov.harvard.edu

Hooghe, Marc, and Ruth Dassonneville. 2018. "Explaining the Trump Vote: The Effect of Racist Resentment and Anti-Immigrant Sentiments". PS: Political Science \& Politics. 51(3): 528-534.

Kinder, Donald R., and Lynn M. Sanders. 1996. Divided by Color: Racial Politics and Democratic Ideals. Chicago: University of Chicago Press.

King, Gary, Michael Tomz, and Jason Wittenberg. 2000. "Making the Most of Statistical Analyses: Improving Interpretation and Presentation". American Journal of Political Science 44(2): 347-61.

Meyer, Chase B., and J. David Woodard. 2017. "It's Not Race, It's Politics! A Natural Experiment Examining the Influence of Race in Electoral Politics". Social Science Quarterly 98(1): 120-131.

Neville, Helen A., Roderick L. Lilly, Georgia Duran, Richard M. Lee, and LaVonne Browne. 2000. "Construction and Initial Validation of the Color-Blind Racial Attitudes Scale (CoBRAS)". Journal of Counseling Psychology 47(1): 59-70.

Rabinowitz, Joshua L., David O. Sears, Jim Sidanius, and Jon A. Krosnick. 2009. "Why Do White Americans Oppose Race-Targeted Policies? Clarifying the Impact of Symbolic Racism". Political Psychology 30(5): 805-28.

R Core Team. 2018. R: A Language and Environment for Statistical Computing. R Foundation for Statistical Computing, Vienna, Austria. URL https://www.Rproject.org/.

Schaffner, Brian F., Matthew MacWilliams, and Tatishe Nteta. 2018. "Understanding White Polarization in the 2016 Vote for President: The Sobering Role of Racism and Sexism". Political Science Quarterly 133(1): 9-34.

Spanierman, Lisa B., and Mary J. Heppner. 2004. "Psychosocial Costs of Racism to Whites Scale (PCRW): Construction and Initial Validation". Journal of Counseling Psychology 51(2): 249-262.

StataCorp. 2017. Stata Statistical Software: Release 15. College Station, TX: StataCorp LLC. 
Tesler, Michael. 2012. "The Spillover of Racialization into Health Care: How President Obama Polarized Public Opinion by Racial Attitudes and Race". American Journal of Political Science 56(3): 690-704.

Tomz, Michael, Jason Wittenberg, and Gary King. 2001. CLARIFY: Software for Interpreting and Presenting Statistical Results. Version 2.0 Cambridge, MA: Harvard University, June 1. http://gking.harvard.edu

White Jr, Paul, and Robert W. Oldendick. 2016. "Can Partisanship Trump Racism? White Voter Support for Black Republican Candidates". Journal of Political Science 44: 135156.

Wickham, Hadley. 2016. ggplot2: Elegant Graphics for Data Analysis. Springer-Verlag New York.

Zigerell, L. J. 2015. "Distinguishing Racism from Ideology: A Methodological Inquiry". Political Research Quarterly 68(3): 521-536. 


\section{Supplemental Material}

Section S1. ANES 2016 Analysis

\begin{tabular}{|c|c|c|c|c|c|c|c|c|}
\hline \multirow{2}{*}{\multicolumn{2}{|c|}{ Table S1-1 }} & \multicolumn{7}{|c|}{ Discrimination in the U.S. against Whites } \\
\hline & & \multirow{2}{*}{$\begin{array}{c}\text { Refused } \\
13\end{array}$} & \multirow{2}{*}{$\begin{array}{c}\begin{array}{c}\text { A great } \\
\text { deal }\end{array} \\
1\end{array}$} & \multirow{2}{*}{$\frac{\text { A lot }}{1}$} & \multirow{2}{*}{$\begin{array}{c}\mathrm{A} \\
\text { moderate } \\
\text { amount } \\
3\end{array}$} & \multirow{2}{*}{$\begin{array}{c}\text { A little } \\
6\end{array}$} & \multirow{2}{*}{$\begin{array}{c}\begin{array}{c}\text { None at } \\
\text { all }\end{array} \\
1\end{array}$} & \multirow{2}{*}{$\begin{array}{c}\text { Total } \\
25\end{array}$} \\
\hline \multirow{7}{*}{ 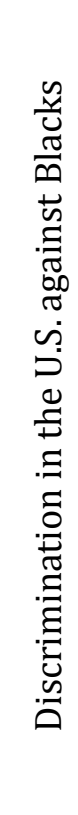 } & Refused & & & & & & & \\
\hline & $\begin{array}{c}\text { A great } \\
\text { deal }\end{array}$ & 0 & 8 & 1 & 13 & 16 & 5 & 43 \\
\hline & A lot & 4 & 1 & 24 & 47 & 77 & 32 & 185 \\
\hline & $\begin{array}{c}\text { A } \\
\text { moderate } \\
\text { amount }\end{array}$ & 6 & 7 & 31 & 143 & 256 & 58 & 501 \\
\hline & A little & 6 & 16 & 23 & 36 & 174 & 36 & 291 \\
\hline & $\begin{array}{c}\text { None at } \\
\text { all }\end{array}$ & 1 & 4 & 2 & 4 & 8 & 34 & 53 \\
\hline & Total & 30 & 37 & 82 & 246 & 537 & 166 & 1,098 \\
\hline
\end{tabular}

Note: Cells indicate the number of non-Hispanic White participants who voted for Donald Trump in the 2016 U.S. presidential election and had the indicated responses to the items measuring perceived discrimination against Blacks in the United States today and against Whites in the United States today. Blue vertical-striped cells indicate participants who denied discrimination against Blacks but indicated that there is some discrimination against Whites. Green horizontal-striped cells indicate participants who denied discrimination against Whites but indicated that there is some discrimination against Blacks. Purple unstriped cells indicate participants who rated discrimination against Blacks less than discrimination against Whites but were not included in the blue cells. Item wording: "How much discrimination is there in the United States today against each of the following groups?:" Blacks and Whites were among the included target groups. [Options: A great deal, A lot, A moderate amount, A little, None at all]. Data Source: ANES 2016 Time Series Study. 
Section S2. CCES 2016 Analysis

Section S2-1. Summary statistics

Data are for non-Hispanic White respondents only

\begin{tabular}{|c|c|c|c|c|c|c|}
\hline \multicolumn{7}{|c|}{ Table S2-1 } \\
\hline Variable & $\mathrm{N}$ & Mean & $\begin{array}{l}\text { Std. } \\
\text { Dev. }\end{array}$ & Min & Max & Levels \\
\hline Racist resentment & 39,925 & 0.33 & 0.24 & 0 & 1 & 13 \\
\hline $\begin{array}{l}\text { Vote for Donald Trump in the } 2016 \text { U.S. } \\
\text { presidential election }\end{array}$ & 31,476 & 0.52 & 0.50 & 0 & 1 & 2 \\
\hline $\begin{array}{l}\text { Opposition to same-sex marriage being } \\
\text { legal }\end{array}$ & 39,780 & 0.35 & 0.48 & 0 & 1 & 2 \\
\hline $\begin{array}{l}\text { Opposition to the Highway and } \\
\text { Transportation Funding Act }\end{array}$ & 39,986 & 0.16 & 0.36 & 0 & 1 & 2 \\
\hline $\begin{array}{l}\text { Opposition to a woman always being } \\
\text { allowed to obtain an abortion }\end{array}$ & 40,063 & 0.41 & 0.49 & 0 & 1 & 2 \\
\hline $\begin{array}{l}\text { Vote for Hillary Clinton in the } 2016 \\
\text { Democratic Party Primary }\end{array}$ & 12,138 & 0.52 & 0.50 & 0 & 1 & 2 \\
\hline $\begin{array}{l}\text { Summed scale of attitudes about } \\
\text { environmental policy proposals }\end{array}$ & 40,033 & 0.38 & 0.39 & 0 & 1 & 5 \\
\hline $\begin{array}{l}\text { Support for decreased state spending on } \\
\text { transportation and infrastructure }\end{array}$ & 39,974 & 0.31 & 0.23 & 0 & 1 & 5 \\
\hline $\begin{array}{l}\text { Support for decreased state spending on } \\
\text { education }\end{array}$ & 39,977 & 0.30 & 0.27 & 0 & 1 & 5 \\
\hline Job approval for Senator Tim Scott & 361 & 0.65 & 0.35 & 0 & 1 & 4 \\
\hline Job approval for Senator Lindsey Graham & 420 & 0.35 & 0.30 & 0 & 1 & 4 \\
\hline $\begin{array}{l}\text { Opposition to eliminating mandatory } \\
\text { minimum sentences for non-violent drug } \\
\text { offenders }\end{array}$ & 40,075 & 0.35 & 0.48 & 0 & 1 & 2 \\
\hline $\begin{array}{l}\text { Opposition to requiring on-duty police to } \\
\text { wear body cams }\end{array}$ & 40,072 & 0.14 & 0.35 & 0 & 1 & 2 \\
\hline $\begin{array}{l}\text { Opposition to increasing police on the } \\
\text { street by } 10 \text { percent }\end{array}$ & 40,056 & 0.43 & 0.49 & 0 & 1 & 2 \\
\hline $\begin{array}{l}\text { Opposition to increasing sentences for } \\
\text { felons with } 2+\text { serious or violent crimes }\end{array}$ & 40,068 & 0.14 & 0.35 & 0 & 1 & 2 \\
\hline $\begin{array}{l}\text { Opposition to giving the EPA the power to } \\
\text { regulate CO2 emissions }\end{array}$ & 40,058 & 0.36 & 0.48 & 0 & 1 & 2 \\
\hline $\begin{array}{l}\text { Opposition to raising auto fuel efficiency } \\
\text { standards }\end{array}$ & 40,064 & 0.32 & 0.47 & 0 & 1 & 2 \\
\hline
\end{tabular}




\begin{tabular}{|lcccccc|}
\hline $\begin{array}{l}\text { Opposition to requiring a minimum } \\
\text { amount of renewable fuels in generation } \\
\text { of electricity }\end{array}$ & 40,057 & 0.38 & 0.49 & 0 & 1 & 2 \\
\hline $\begin{array}{l}\text { Opposition to strengthening enforcement } \\
\text { of the Clean Air Act and Clean Water Act }\end{array}$ & 40,065 & 0.46 & 0.50 & 0 & 1 & 2 \\
\hline Participant age & 40,099 & 0.44 & 0.21 & 0 & 1 & 78 \\
\hline Participant sex (female) & 40,099 & 0.56 & 0.50 & 0 & 1 & 2 \\
\hline Participant education & 40,099 & 0.54 & 0.30 & 0 & 1 & 6 \\
\hline Family income $<\$ 40 \mathrm{k}$ & 40,099 & 0.29 & 0.45 & 0 & 1 & 2 \\
\hline Family income 40k-79k & 40,099 & 0.32 & 0.47 & 0 & 1 & 2 \\
\hline Family income 80k-119k & 40,099 & 0.16 & 0.37 & 0 & 1 & 2 \\
\hline Family income 120k+ & 40,099 & 0.12 & 0.32 & 0 & 1 & 2 \\
\hline Participant partisanship (GOP higher) & 40,074 & 0.48 & 0.35 & 0 & 1 & 7 \\
\hline Participant ideology (conservative higher) & 40,086 & 0.52 & 0.27 & 0 & 1 & 5 \\
\hline
\end{tabular}

\section{Section S2-2. Selected item text}

- Racist resentment: [1] "I am angry that racism exists" [2] "White people in the U.S. have certain advantages because of the color of their skin" [3] "I often find myself fearful of people of other races" [4] "Racial problems in the U.S. are rare, isolated situations". [Options: strongly agree, somewhat agree, neither agree nor disagree, somewhat disagree, strongly disagree]. Note that item 3 was not included in the racist resentment measure for the main analysis.

- Vote for Donald Trump in the 2016 U.S. presidential election: "For whom did you vote for President of the United States?" [Options included: Donald Trump (Republican), Hillary Clinton (Democrat)]

- Opposition to same-sex marriage being legal: "Do you favor or oppose allowing gays and lesbians to marry legally?" [Options: favor, oppose]

- Opposition to the Highway and Transportation Funding Act: "Congress considers many issues. If you were in Congress would you vote FOR or AGAINST each of the following?: Highway and Transportation Funding Act. Authorizes \$305 Billion to repair and expand highways, bridges, and transit over the next 5 years." [Options: for, against]

- Opposition to a woman always being allowed to obtain an abortion: "Do you support or oppose each of the following proposals?: Always allow a woman to obtain an abortion as a matter of choice". [Options: support, oppose]

- Vote for Hillary Clinton in the 2016 Democratic Party primary election: "In the Presidential primary or caucus, who did you vote for?" [Options included: Hillary Clinton, Bernie Sanders] 
- Summed scale of attitudes about environmental policy proposals: "Do you support or oppose each of the following proposals?: [1] Give Environmental Protection Agency power to regulate Carbon Dioxide emissions. [2] Raise required fuel efficiency for the average automobile from $25 \mathrm{mpg}$ to $35 \mathrm{mpg}$. [3] Require a minimum amount of renewable fuels (wind, solar, and hydroelectric) in the generation of electricity even if electricity prices increase somewhat. [4] Strengthen enforcement of the Clean Air Act and Clean Water Act even if it costs US jobs". [Options: support, oppose]

- Support for decreased state spending on transportation and infrastructure: "State legislatures must make choices when making spending decisions on important state programs. Would you like your legislature to increase or decrease spending on the five areas below?: Transportation/Infrastructure". [Options: greatly increase, slightly increase, maintain, slightly decrease, greatly decrease]

- Support for decreased state spending on education: "State legislatures must make choices when making spending decisions on important state programs. Would you like your legislature to increase or decrease spending on the five areas below?: Education". [Options: greatly increase, slightly increase, maintain, slightly decrease, greatly decrease]

- Job approval for Senator Tim Scott and Senator Lindsey Graham: "Do you approve of the way each is doing their job...". [Options: strongly approve, somewhat approve, somewhat disapprove, strongly disapprove]

- Opposition to eliminating mandatory minimum sentences for non-violent drug offenders: "Do you support or oppose each of the following proposals?: Eliminate mandatory minimum sentences for non-violent drug offenders". [Options: support, oppose]

- Opposition to requiring on-duty police to wear body cams: "Do you support or oppose each of the following proposals?: Require police officers to wear body cameras that record all of their activities while on duty". [Options: support, oppose]

- Opposition to increasing police on the street by 10 percent: "Do you support or oppose each of the following proposals?: Increase the number of police on the street by 10 percent, even if it means fewer funds for other public services". [Options: support, oppose]

- Opposition to increasing sentences for felons with 2+ serious or violent crimes: "Do you support or oppose each of the following proposals?: Increase prison sentences for felons who have already committed two or more serious or violent crimes". [Options: support, oppose]

- Opposition to giving the EPA the power to regulate CO2 emissions: "Do you support or oppose each of the following proposals?: Give Environmental Protection Agency power to regulate Carbon Dioxide emissions". [Options: support, oppose] 
- Opposition to raising auto fuel efficiency standards: "Do you support or oppose each of the following proposals?: Raise required fuel efficiency for the average automobile from $25 \mathrm{mpg}$ to $35 \mathrm{mpg}$ ". [Options: support, oppose]

- Opposition to requiring a minimum amount of renewable fuels in generation of electricity: "Do you support or oppose each of the following proposals?: Require a minimum amount of renewable fuels (wind, solar, and hydroelectric) in the generation of electricity even if electricity prices increase somewhat". [Options: support, oppose]

- Opposition to strengthening enforcement of the Clean Air Act and Clean Water Act: "Do you support or oppose each of the following proposals?: Strengthen enforcement of the Clean Air Act and Clean Water Act even if it costs US jobs". [Options: support, oppose]

\section{Section S2-3. Notes on variable coding}

- Participant family income: Participants who did not provide a substantive response were coded as the omitted category in the main analysis.

- Participant partisanship: Participants who indicated that they were not sure of their partisanship were listwise deleted from the main analysis.

- Participant ideology: Participants who indicated that they were not sure of their ideology were listwise deleted from the main analysis. 
$\underline{\text { Section S2-4. Regression output for the Figure } 1 \text { models }}$

\begin{tabular}{|c|c|c|c|c|c|}
\hline & 1 & 2 & 3 & 4 & 5 \\
\hline Table S2-4-A & $\begin{array}{c}\text { Vote for Donald } \\
\text { Trump }\end{array}$ & $\begin{array}{c}\text { Opposition to } \\
\text { legal same-sex } \\
\text { marriage }\end{array}$ & $\begin{array}{l}\text { Highway and } \\
\text { Transportation } \\
\text { Funding Act }\end{array}$ & $\begin{array}{l}\text { Opposition to } \\
\text { legal abortion }\end{array}$ & $\begin{array}{l}\text { Democratic Party } \\
\text { primary vote for } \\
\text { Hillary Clinton }\end{array}$ \\
\hline Racist resentment & $\begin{array}{l}6.267^{*} \\
(0.135)\end{array}$ & $\begin{array}{l}2.089 * \\
(0.069)\end{array}$ & $\begin{array}{c}1.824^{*} \\
(0.076)\end{array}$ & $\begin{array}{l}1.265^{*} \\
(0.064)\end{array}$ & $\begin{array}{l}0.590^{*} \\
(0.128)\end{array}$ \\
\hline Female & $\begin{array}{c}-0.152^{*} \\
(0.049)\end{array}$ & $\begin{array}{l}-0.209^{*} \\
(0.028)\end{array}$ & $\begin{array}{c}0.555^{*} \\
(0.032)\end{array}$ & $\begin{array}{c}-0.045 \\
(0.026)\end{array}$ & $\begin{array}{c}0.117^{*} \\
(0.041)\end{array}$ \\
\hline Age & $\begin{array}{c}0.213 \\
(0.127)\end{array}$ & $\begin{array}{l}1.224^{*} \\
(0.073)\end{array}$ & $\begin{array}{l}-2.055^{*} \\
(0.080)\end{array}$ & $\begin{array}{l}-0.166^{*} \\
(0.067)\end{array}$ & $\begin{array}{l}1.347^{*} \\
(0.099)\end{array}$ \\
\hline Education & $\begin{array}{l}-1.009 * \\
(0.091)\end{array}$ & $\begin{array}{l}-0.416^{*} \\
(0.052)\end{array}$ & $\begin{array}{l}-0.232^{*} \\
(0.057)\end{array}$ & $\begin{array}{c}0.117^{*} \\
(0.048)\end{array}$ & $\begin{array}{c}0.335^{*} \\
(0.076)\end{array}$ \\
\hline Family income $<\$ 40 \mathrm{k}$ & $\begin{array}{c}0.001 \\
(0.090)\end{array}$ & $\begin{array}{l}0.110^{*} \\
(0.050)\end{array}$ & $\begin{array}{c}-0.043 \\
(0.055)\end{array}$ & $\begin{array}{c}0.137^{*} \\
(0.046)\end{array}$ & $\begin{array}{c}-0.024 \\
(0.078)\end{array}$ \\
\hline Family income $40 \mathrm{k}-79 \mathrm{k}$ & $\begin{array}{c}0.035 \\
(0.087)\end{array}$ & $\begin{array}{c}-0.058 \\
(0.049)\end{array}$ & $\begin{array}{c}-0.036 \\
(0.054)\end{array}$ & $\begin{array}{c}0.044 \\
(0.045)\end{array}$ & $\begin{array}{c}0.119 \\
(0.075)\end{array}$ \\
\hline Family income $80 \mathrm{k}-119 \mathrm{k}$ & $\begin{array}{c}-0.090 \\
(0.096)\end{array}$ & $\begin{array}{l}-0.155^{*} \\
(0.055)\end{array}$ & $\begin{array}{c}-0.042 \\
(0.060)\end{array}$ & $\begin{array}{l}-0.087 \\
(0.050)\end{array}$ & $\begin{array}{c}0.307^{*} \\
(0.081)\end{array}$ \\
\hline Family income $120 \mathrm{k}+$ & $\begin{array}{l}-0.342^{*} \\
(0.103)\end{array}$ & $\begin{array}{l}-0.478^{*} \\
(0.060)\end{array}$ & $\begin{array}{l}-0.147^{*} \\
(0.067)\end{array}$ & $\begin{array}{l}-0.285^{*} \\
(0.055)\end{array}$ & $\begin{array}{l}0.698^{*} \\
(0.086)\end{array}$ \\
\hline Partisanship & $\begin{array}{c}5.433^{*} \\
(0.088)\end{array}$ & $\begin{array}{l}1.074^{*} \\
(0.051)\end{array}$ & $\begin{array}{c}0.338^{*} \\
(0.059)\end{array}$ & $\begin{array}{c}1.245^{*} \\
(0.047)\end{array}$ & $\begin{array}{l}-3.856^{*} \\
(0.118)\end{array}$ \\
\hline Ideology & $\begin{array}{c}3.740^{*} \\
(0.135)\end{array}$ & $\begin{array}{l}3.994^{*} \\
(0.080)\end{array}$ & $\begin{array}{c}1.110^{*} \\
(0.080)\end{array}$ & $\begin{array}{l}3.322^{*} \\
(0.071)\end{array}$ & $\begin{array}{l}2.313^{*} \\
(0.110)\end{array}$ \\
\hline Constant & $\begin{array}{l}-5.783^{*} \\
(0.148)\end{array}$ & $\begin{array}{l}-4.418^{*} \\
(0.084)\end{array}$ & $\begin{array}{l}-2.526^{*} \\
(0.084)\end{array}$ & $\begin{array}{l}-3.253^{*} \\
(0.074)\end{array}$ & $\begin{array}{l}-1.199 * \\
(0.109)\end{array}$ \\
\hline Observations & 30269 & 36788 & 36979 & 37045 & 11792 \\
\hline
\end{tabular}




\begin{tabular}{|c|c|c|c|c|c|}
\hline & 6 & 7 & 8 & 9 & 10 \\
\hline Table S2-4-B & $\begin{array}{l}\text { Attitudes about } \\
\text { environmental } \\
\text { policy proposals }\end{array}$ & $\begin{array}{l}\text { Decreased state } \\
\text { spending on } \\
\text { transportation / } \\
\text { infrastructure }\end{array}$ & $\begin{array}{l}\text { Decreased state } \\
\text { spending on } \\
\text { education }\end{array}$ & $\begin{array}{l}\text { Job approval for } \\
\text { South Carolina } \\
\text { senator Tim } \\
\text { Scott }\end{array}$ & $\begin{array}{c}\text { Job approval for } \\
\text { South Carolina } \\
\text { senator Lindsey } \\
\text { Graham }\end{array}$ \\
\hline Racist resentment & $\begin{array}{c}0.574^{*} \\
(0.008) \\
\end{array}$ & $\begin{array}{c}0.151^{*} \\
(0.006) \\
\end{array}$ & $\begin{array}{c}0.360 * \\
(0.006)\end{array}$ & $\begin{array}{c}0.293^{*} \\
(0.074) \\
\end{array}$ & $\begin{array}{c}-0.160 * \\
(0.078) \\
\end{array}$ \\
\hline Female & $\begin{array}{c}-0.037^{*} \\
(0.003)\end{array}$ & $\begin{array}{c}0.063^{*} \\
(0.002)\end{array}$ & $\begin{array}{l}-0.021^{*} \\
(0.003)\end{array}$ & $\begin{array}{c}0.018 \\
(0.030)\end{array}$ & $\begin{array}{c}0.064^{*} \\
(0.031)\end{array}$ \\
\hline Age & $\begin{array}{c}0.112^{*} \\
(0.008)\end{array}$ & $\begin{array}{l}-0.137^{*} \\
(0.006)\end{array}$ & $\begin{array}{c}0.079 * \\
(0.006)\end{array}$ & $\begin{array}{c}0.205^{*} \\
(0.082)\end{array}$ & $\begin{array}{c}0.099 \\
(0.080)\end{array}$ \\
\hline Education & $\begin{array}{c}0.023^{*} \\
(0.006)\end{array}$ & $\begin{array}{c}-0.057^{*} \\
(0.004)\end{array}$ & $\begin{array}{c}0.015^{*} \\
(0.005)\end{array}$ & $\begin{array}{c}-0.068 \\
(0.056)\end{array}$ & $\begin{array}{c}0.045 \\
(0.058)\end{array}$ \\
\hline Family income $<\$ 40 \mathrm{k}$ & $\begin{array}{l}-0.053^{*} \\
(0.006)\end{array}$ & $\begin{array}{l}0.009^{*} \\
(0.004)\end{array}$ & $\begin{array}{l}-0.025^{*} \\
(0.005)\end{array}$ & $\begin{array}{l}-0.002 \\
(0.056)\end{array}$ & $\begin{array}{c}0.076 \\
(0.057)\end{array}$ \\
\hline Family income $40 \mathrm{k}-79 \mathrm{k}$ & $\begin{array}{l}-0.035^{*} \\
(0.005)\end{array}$ & $\begin{array}{c}0.005 \\
(0.004)\end{array}$ & $\begin{array}{l}-0.013^{*} \\
(0.004)\end{array}$ & $\begin{array}{c}0.074 \\
(0.054)\end{array}$ & $\begin{array}{c}0.027 \\
(0.055)\end{array}$ \\
\hline Family income $80 \mathrm{k}-119 \mathrm{k}$ & $\begin{array}{l}-0.035^{*} \\
(0.006)\end{array}$ & $\begin{array}{c}-0.002 \\
(0.005) \\
\end{array}$ & $\begin{array}{l}-0.013^{*} \\
(0.005)\end{array}$ & $\begin{array}{c}0.114 \\
(0.060)\end{array}$ & $\begin{array}{c}0.094 \\
(0.061) \\
\end{array}$ \\
\hline Family income $120 \mathrm{k}+$ & $\begin{array}{l}-0.040 * \\
(0.006)\end{array}$ & $\begin{array}{c}-0.018^{*} \\
(0.005)\end{array}$ & $\begin{array}{c}-0.008 \\
(0.005)\end{array}$ & $\begin{array}{c}0.097 \\
(0.071)\end{array}$ & $\begin{array}{c}0.092 \\
(0.073)\end{array}$ \\
\hline Partisanship & $\begin{array}{c}0.241^{*} \\
(0.006)\end{array}$ & $\begin{array}{c}0.032^{*} \\
(0.004)\end{array}$ & $\begin{array}{c}0.048^{*} \\
(0.005)\end{array}$ & $\begin{array}{c}0.515^{*} \\
(0.067)\end{array}$ & $\begin{array}{c}0.192^{*} \\
(0.065)\end{array}$ \\
\hline Ideology & $\begin{array}{c}0.285^{*} \\
(0.008)\end{array}$ & $\begin{array}{c}0.099 * \\
(0.006)\end{array}$ & $\begin{array}{c}0.154^{*} \\
(0.006)\end{array}$ & $\begin{array}{c}0.038 \\
(0.078)\end{array}$ & $\begin{array}{c}-0.092 \\
(0.079)\end{array}$ \\
\hline Constant & $\begin{array}{l}-0.078^{*} \\
(0.008)\end{array}$ & $\begin{array}{c}0.240^{*} \\
(0.006)\end{array}$ & $\begin{array}{c}0.065^{*} \\
(0.007)\end{array}$ & $\begin{array}{c}0.068 \\
(0.087)\end{array}$ & $\begin{array}{c}0.177^{*} \\
(0.085)\end{array}$ \\
\hline Observations & 37016 & 36974 & 36963 & 351 & 407 \\
\hline
\end{tabular}


$\underline{\text { Section S2-5. Information on Figure } 1 \text { robustness checks }}$

\begin{tabular}{|c|c|c|c|c|c|c|c|c|c|c|}
\hline \multicolumn{11}{|c|}{ P-values for the racist resentment variable in alternate model specifications } \\
\hline Table S2-5 & 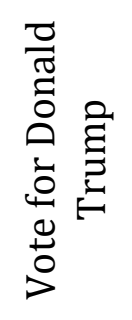 & 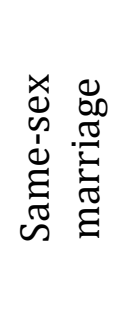 & 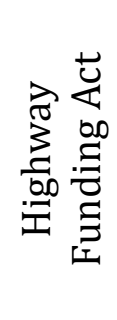 & 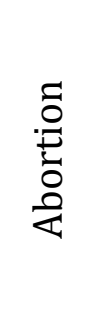 & 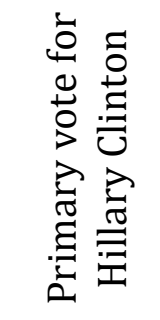 & 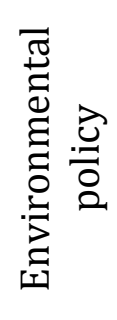 & 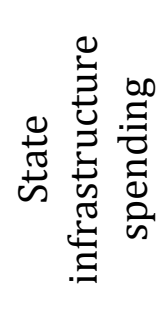 & 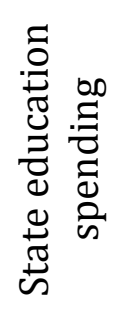 & 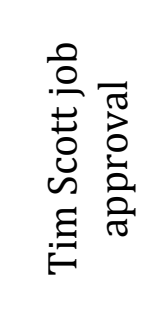 & 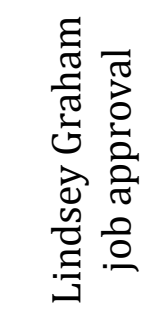 \\
\hline $\begin{array}{l}\text { [1] The main model } \\
\text { using fractional logistic } \\
\text { regression }\end{array}$ & NA & NA & NA & NA & NA & . & . & . & . & $\mathrm{p}=0.040$ \\
\hline $\begin{array}{l}\text { [2] The main model } \\
\text { with survey weights }\end{array}$ & . & . & . & . & $\mathrm{p}=0.023$ & ${ }^{\circ}$ & . & . & $\mathrm{p}=0.002$ & $\mathrm{p}=0.088$ \\
\hline $\begin{array}{l}\text { [2A] Model [2] using } \\
\text { fractional logistic } \\
\text { regression }\end{array}$ & NA & NA & NA & NA & NA & . & . & . & $\mathrm{p}=0.013$ & $\mathrm{p}=0.090$ \\
\hline $\begin{array}{l}\text { [3] The main model } \\
\text { using a racist } \\
\text { resentment measure } \\
\text { that summed the four } \\
\text { "racist resentment" } \\
\text { items on the } 2016 \\
\text { CCES }\end{array}$ & . & $\cdot$ & $\cdot$ & $\cdot$ & $\cdot$ & . & $\cdot$ & . & $\mathrm{p}=0.007$ & $\mathrm{p}=0.148$ \\
\hline $\begin{array}{l}\text { [3A] Model [3] using } \\
\text { fractional logistic } \\
\text { regression }\end{array}$ & NA & NA & NA & NA & NA & . & . & . & $\mathrm{p}=0.017$ & $\mathrm{p}=0.154$ \\
\hline $\begin{array}{l}\text { [3B] Model [3] with } \\
\text { survey weights }\end{array}$ & . & & . & . & . & & . & . & $\mathrm{p}=0.040$ & $\mathrm{p}=0.271$ \\
\hline $\begin{array}{l}\text { [3C] Model [3B] with } \\
\text { survey weights }\end{array}$ & NA & NA & NA & NA & NA & . & . & . & $\mathrm{p}=0.090$ & $\mathrm{p}=0.270$ \\
\hline
\end{tabular}




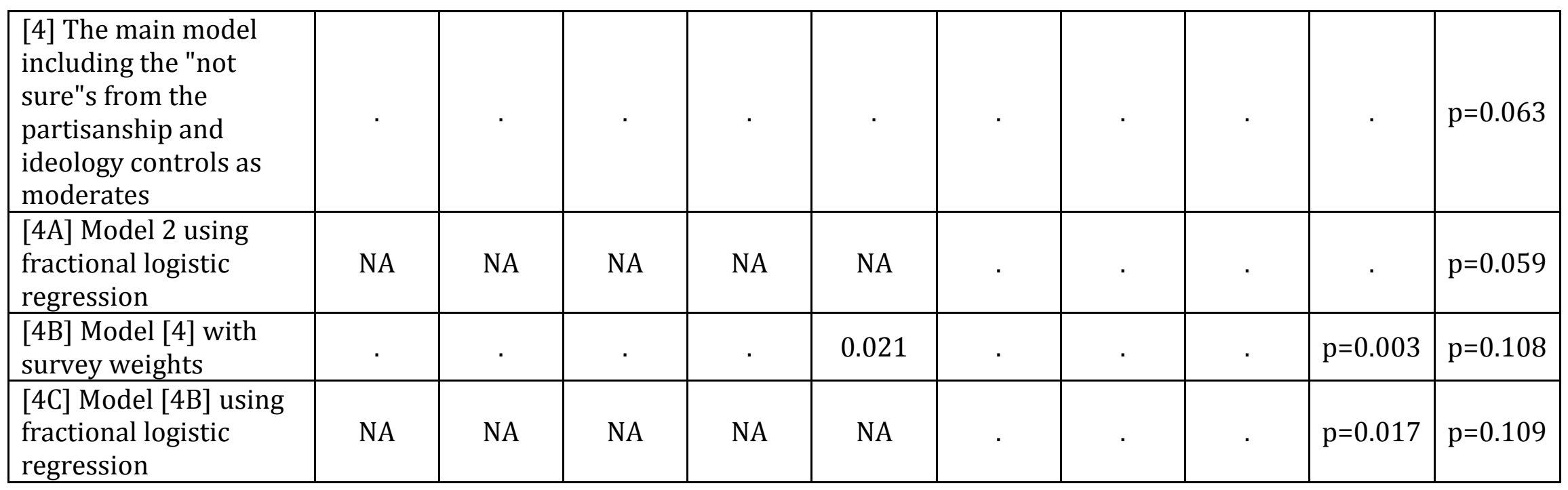

Note: Dots (.) indicates regressions in which the $\mathrm{p}$-value for the racist resentment measure was less than $\mathrm{p}=0.001$. 

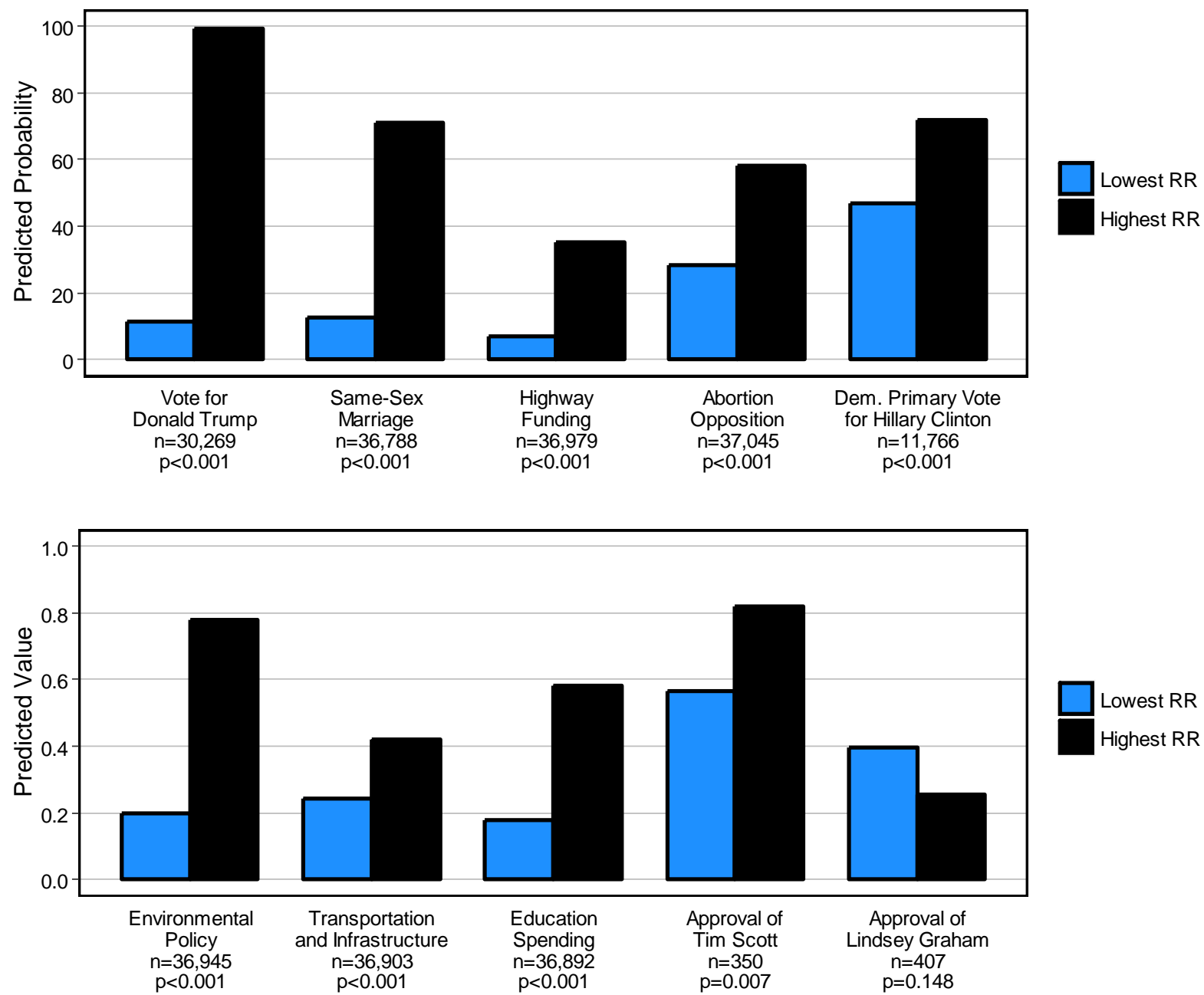

Figure S2. Association of Racist Resentment with Selected Outcome Variables See the note for Figure 1. This figure is for the main model using a racist resentment measure that summed the four "racist resentment" items on the 2016 CCES. Data source: CCES 2016. The figure was produced in R (R Core Team 2018) using ggplot2 (Wickham 2016). 